\title{
The Application of the Precautionary and Adaptive Management Approaches in the Seabed Mining Context: Trans-Tasman Resources Ltd Marine Consent Decision under New Zealand's Exclusive Economic Zone and Continental Shelf (Environmental Effects) Act 2012
}

\author{
Rakhyun E. Kim* \& Donald K. Anton ${ }^{* *}$ \\ ANU College of Law \\ The Australian National University
}

This note analyses a recent path-breaking decision by the Decision-making Committee (DMC) of the Environmental Protection Authority (EPA) of New Zealand. In Trans-Tasman Resources Ltd Marine Consent Decision (June 2014), ${ }^{1}$ the DMC considered the country's first application for 'marine consent' for continental shelf seabed mining under the Exclusive Economic Zone and Continental Shelf (Environmental Effects) Act 2012 (EEZ Act). ${ }^{2}$ The EEZ Act came into force on 28 June 2013 and set up a legislative framework to regulate and manage the environmental effects of activities in the exclusive economic zone and on the continental shelf, which were not previously managed.

\footnotetext{
${ }^{*}$ Research Fellow, The Australian National University College of Law.

** Professor of Law, The Australian National University College of Law.

${ }^{1}$ Environmental Protection Authority, Trans-Tasman Resources Ltd Marine Consent Decision, June 2014, available at http://www.epa.govt.nz/EEZ/EEZ000004/Trans_Tasman_Resources_decision_17June2014.pdf [hereinafter Trans-Tasman Decision].

${ }^{2}$ Exclusive Economic Zone and Continental Shelf (Environmental Effects) Act 2012, No. 72 (2012)
} (New Zealand) [hereinafter EEZ Act]. Under section 38 of the Act, any person may apply to the EPA for a marine consent to undertake a discretionary activity defined in Article 36 and described in the Exclusive Economic Zone and Continental Shelf (Environmental Effects-Permitted Activities) Regulations 2013. 
In the instant case, the DMC refused to grant a marine consent because it decided that the consent application was 'premature'. ${ }^{3}$ The decision has attracted considerable attention $^{4}$ as it comes against the backdrop of the worldwide resurgence of interest in deep seabed mining. ${ }^{5}$ Nationally, there were 4,702 public submissions made to the EPA, among which 4,680 opposed the application. ${ }^{6}$ For those against the

${ }^{3}$ Trans-Tasman Decision (n 1), at para. 853.

${ }^{4}$ See, e.g., 'NZ no to seabed mining a cautionary tale for the Pacific', ABC Radio Australia, 25 June 2014, available at http://www.radioaustralia.net.au/international/radio/program/pacific-beat/nz-no-toseabed-mining-a-cautionary-tale-for-the-pacific/1332558; 'Cooks to learn from seabed mining refusal', Cook Island News, June 21, 2014, available at http://www.cookislandsnews.com/item/47303-cooks-tolearn-from-seabed-mining-refusal/47303-cooks-to-learn-from-seabed-mining-refusal; 'Mining sector in shock over seabed mining rejection' The New Zealand Herald, June 19, 2014, available at http://www.nzherald.co.nz/business/news/article.cfm?c_id=3\&objectid=11277331; 'Seabed mining bid rejection a "victory for common sense" - environmentalists', TVNZ One News, June 18, 2014, available at http://tvnz.co.nz/national-news/seabed-mining-bid-rejection-victory-common-senseenvironmentalists-6005686; 'New Zealand rejects mining project on Pacific seafloor' New York Times, June 18, 2014, available at http://www.nytimes.com/2014/06/19/business/international/new-zealandrejects-mining-project-on-pacific-seafloor.html; 'NZ EPA refuses consent for undersea iron sands mining', Australian Mining, 18 June 2014, available at http://www.miningaustralia.com.au/news/nzepa-refuses-consent-for-undersea-iron-sands-min.

${ }^{5}$ Increasing international interest in seabed mining beyond national jurisdiction is evidenced by the fact that the number of exploration contracts approved by the International Seabed Authority has increased to an impressive 26 as of September 2014. See further, M. Schrope, 'UK company pursues deep-sea bonanza' (2013) 495 Nature 294; J. Qiu, 'China outlines deep-sea ambitions' (2010) 466 Nature 166; K.S. Jayaraman, 'Steaming ahead' (2007) 448 Nature 642-643; M. Schrope, 'Digging deep' (2007) 447 Nature 246-247; K.S. Jayaraman, 'Deep-sea nuggets prove irresistible to Indian miners’ (2002) 417 Nature 212.

${ }^{6}$ Section 46 of the EEZ Act entitles any person to make a submission about an application for a marine consent. Under section 59(3)(a), the EPA must have regard to all submissions in considering an 
idea of seabed mining, the EPA's permit denial set a positive precedent, but came as a shock to the mining sector. ${ }^{7}$

In this note, we provide an overview of how the EPA interpreted and applied the provisions of the EEZ Act in making its decision. We then discuss implications of the EEZ Act and the DMC's decision for future seabed mining activities both within and beyond national jurisdiction, with a particular emphasis on Pacific Island developing countries. As more states seek to explore and exploit mineral resources of their continental shelves, the international implications will assume an increasing importance.

In particular, the international aspects of mining the seabed of the continental shelf raises issues under Articles 56(2) and 77(1) of the United Nations Convention on the Law of the Sea (LOSC). Under Article 77, it is certain that New Zealand has the sovereign right to explore and exploit the mineral resources of the seabed of its continental shelf. At the same time, Article 56 requires New Zealand to have due regard to the rights of other states and must only permit seabed mining that is compatible with the provisions of the LOSC, including applicable conservation provisions in Part XII and elsewhere. Seabed mining on the continental shelf that

application for a marine consent. Section 29D, however, allows regulations to create a class of activities that require marine consents but without public notification or comment. The Exclusive Economic Zone and Continental Shelf (Environmental Effects - Non-notified Activities Regulations 2014 put exploration drilling for petroleum into this class. For the EPA's analysis of the submissions received, see Trans-Tasman Resources Ltd (TTR) Marine Consent Application for Offshore Iron Sand Extraction: Analysis of Submissions Report, February 2014, at p. 3, available at http://www.epa.govt.nz/Publications/Analysis\%20of\%20Submissions\%20Report\%20\%20appendix\%203\%20of\%20the\%20EPA_Staff_Report.pdf.

${ }^{7}$ See media reports (n 4). 
fails to have sufficient regard to these rights and provisions may constitute a breach of the LOSC permitting other parties to invoke state responsibility.

\section{The Seabed Mining Application}

The applicant, Trans-Tasman Resources Limited (TTR), a New Zealand company, sought a marine consent under the EEZ Act in order to carry out activities that are restricted under section 20 of the EEZ Act. More specifically, TTR sought consent to extract iron sands containing iron ore from the seabed of the continental shelf and undertake processing operations offshore. ${ }^{8}$ The proposed project was to be located in a seabed area of 65.76 square kilometres in the South Taranaki Bight. The extraction activities were to be carried out in water depths between 20 and 42 metres, on the continental shelf, just beyond the outer limits of the territorial sea (12-19 nautical miles). Up to 50 million tonnes of iron ore was proposed to be extracted per year, for up to 20 years.

Seabed mining technology for the proposed project consisted of a 'crawler' and two vessels of 60,000 and 180,000 tonne capacity. The crawler would extract the sand to the base of the mineralization up to 11 metres blow the seabed. The sand was proposed to be processed on-board the larger vessel known as a floating processing, storage, and offloading vessel. ${ }^{9}$ Around 10 per cent of the extracted material would be processed into iron ore concentrate for export, with tailings discharged via a

\footnotetext{
${ }^{8}$ Trans Tasman Resources Limited, Application for a Marine Consent to Undertake a Discretionary Activity, October 2013, at pp. 3-4, available at http://www.epa.govt.nz/Publications/Final_Application_Form.pdf.

${ }^{9}$ Trans-Tasman Decision (n 1), at para. 21.
} 
deposition pipe approximately 4 metres above the seabed, most of which would be redeposited back into the previously mined area. ${ }^{10}$

TTR prepared an impact assessment of the proposed activity as part of the requirements of a marine consent application. ${ }^{11}$ Among many potential effects on the environment and existing interests (such as fishing) identified by the applicant, the DMC considered the sediment plume and accompanying turbidity created by the deposition of the 'de-ored' sediment most significant. ${ }^{12}$ According to modelling, the plume would have a median extent of approximately 50 kilometres long and up to 20 kilometres wide. ${ }^{13}$ The plume would have particularly significant impacts on the biological productivity, reducing the total primary production in the area of 12,570 square kilometres in the order of 10 per cent, and energy input into the seabed ecosystem by up to 36 per cent. ${ }^{14}$

\footnotetext{
${ }^{10}$ Ibid., at paras. 13 and 27.

${ }^{11}$ EEZ Act (n 2), section 38(2)(c). An impact assessment must include information as set out in section

39. This includes information about the proposed activity, the current state of the area and its surrounding environment, any effects on the environment and existing interests, any consultation undertaken, any possible alternative locations for, or methods for undertaking, the activity that may avoid, remedy, or mitigate any adverse effects, and the measures that the applicant intends to take to avoid, remedy, or mitigate the adverse effects identified.

${ }^{12}$ The EPA was also specifically concerned with the benthic effects, consequent ecosystem effects, and the impacts on existing fishing interests. Ibid., at para. 9.

${ }^{13}$ Ibid., at para. 176.

${ }^{14}$ Ibid., at para. 228.
} 


\section{The Sustainability Test under the EEZ Act}

The purpose of the EEZ Act is 'to promote the sustainable management of the natural resources of the exclusive economic zone and the continental shelf ${ }^{15}$ Sustainable management is in turn defined as:

managing the use, development, and protection of natural resources in a way, or at a rate, that enables people to provide for their economic well-being while(a) sustaining the potential of natural resources (excluding minerals) to meet the reasonably foreseeable needs of future generations; and

(b) safeguarding the life-supporting capacity of the environment; and

(c) avoiding, remedying, or mitigating any adverse effects of activities on the environment. ${ }^{16}$

This statutory purpose was adapted from that of the Resource Management Act 1991 (RMA), ${ }^{17}$ and thus takes a similar form. However, the subjects of sustainable management under the EEZ Act (that is, natural resources) are more limited, ${ }^{18}$ and the focus of the EEZ Act (that is, people's economic well-being) is narrower, than those

\footnotetext{
${ }^{15}$ EEZ Act (n 2), section 10(1).

${ }^{16}$ Ibid., section $10(2)$.

${ }^{17}$ Resource Management Act 1991, No. 69 (1991) (New Zealand), section 5. The RMA is New

Zealand's principal environmental law. It regulates natural resource management activities on land and in the territorial sea. The EEZ Act serves a similar function but for activities in the exclusive economic zone and in or on the continental shelf. These activities include aquaculture, exploration and extraction of petroleum and minerals, marine energy generation, and carbon capture and storage.

${ }^{18}$ Trans-Tasman Decision (n 1), at para. 83.
} 
of the RMA. ${ }^{19}$ It therefore made sense for the EPA to take the view that 'the large body of case law and understanding that has built up in relation to the interpretation of the RMA's provisions cannot be applied uncritically to the different environment and statutory context of the exclusive economic zone and continental shelf', and to employ discretion in interpreting the provisions of the EEZ Act. ${ }^{20}$

Like the RMA, all marine consent applications must ultimately satisfy the sustainable management purpose of the EEZ Act. A significant difference is that there are neither policy statements nor plans to guide how this purpose of the EEZ Act is to be achieved. Instead, the formulation of the decision-making criteria and the application of the information principles provide the necessary guidance. ${ }^{21}$ When considering an application for a marine consent, the EPA must take into account decision-making criteria set out in sections 59 and $60,{ }^{22}$ and apply the information principles in section $61 .^{23}$

The decision-making criteria contain an extensive list of matters. The EPA must take into account, inter alia, 'any effects on the environment or existing interests of allowing the activity', 'the effects on the environment or existing interests of other activities undertaken in the area covered by the application or in its vicinity', 25

\footnotetext{
${ }^{19} \mathrm{Ibid}$, at para. 86. Moreover, difficulties in regulatory integration between the EEZ Act and other New Zealand legislation was exposed early in Greenpeace of New Zealand Incorporated v. The Environmental Protection Authority [2013] NZHC 3482.

${ }^{20}$ Trans-Tasman Decision (n 1), at para. 78.

${ }^{21}$ EEZ Act (n 2), section 10(3).

${ }^{22}$ Ibid., section 10(3)(a).

${ }^{23}$ Ibid., section 10(3)(b).

${ }^{24}$ Ibid., section 59(2)(a).

${ }^{25}$ Ibid., section 59(2)(b).
} 
'the effects on human health that may arise from effects on the environment', 26 'the importance of protecting the biological diversity and integrity of marine species, ecosystems, and processes', ${ }^{27}$ 'the importance of protecting rare and vulnerable ecosystems and the habitats of threatened species', ${ }^{28}$ and 'the economic benefit to New Zealand of allowing the application'. ${ }^{29}$ It should be noted that the term 'effect', which appears in the decision-making criteria as well as the statutory purpose, is defined very broadly to include any positive, adverse, temporary, permanent, past, present, future, cumulative, and highly probable effect, as well as an effect of low probability that has a high potential impact. ${ }^{30}$

What are known as 'information principles' in the EEZ Act, ${ }^{31}$ require the EPA to base decisions on the 'best available information', ${ }^{32}$ which is defined as 'the best information that, in the particular circumstances, is available without unreasonable cost, effort, or time' ${ }^{33}$ Determining what information is the best available information requires the EPA to exercise some judgment. ${ }^{34}$ In the case under analysis, the

\footnotetext{
${ }^{26}$ Ibid., section 59(2)(c).

${ }^{27}$ Ibid., section 59(2)(d).

${ }^{28}$ Ibid., section 59(2)(e).

${ }^{29}$ Ibid., section 59(2)(f).

${ }^{30}$ Ibid., section 6. Such an all-encompassing definition of 'effect' effectively allows a precautionary approach to resource management by requiring resource users to avoid, remedy, or mitigate any potential adverse effect of low probability but high potential impact. For a similar view in the RMA context, see Shirley Primary School v. Telecom Mobile Communications Limited [1999] NZRMA 66.

${ }^{31}$ Ibid., section 61 .

${ }^{32}$ Ibid., section 61(1)(b). Public participation plays a role in generating the best available information for consideration by the EPA. See supra $n$.

${ }^{33}$ Ibid., section 61(5).

${ }^{34}$ Trans-Tasman Decision (n 1), at para. 120; see also para. 128.
} 
information available about the potential adverse effects was deemed uncertain and inadequate by the EPA's DMC. In particular, the absence of baseline monitoring data was considered problematic. ${ }^{35}$ The DMC was of the view that the applicant did not do enough work to study potential effects, notwithstanding the significant amount of time and money invested in preparing for the consent application. ${ }^{36}$

Because the information available was uncertain or inadequate, the DMC was compelled to 'favour caution and environmental protection'. ${ }^{37}$ This requirement is directive, ${ }^{38}$ and an 'absolute one' under the EEZ Act. ${ }^{39}$ It should be noted, however, that favouring caution and environmental protection does not necessarily require the EPA to refuse consent. ${ }^{40}$ Having determined that the EPA is confronted with material uncertainty and inadequacy and therefore it must favour caution and environmental protection, the question then was whether this means the proposed activity is 'likely to be refused' ${ }^{41}$ The DMC in this case decided affirmatively. ${ }^{42}$

\footnotetext{
${ }^{35}$ Ibid., at para. 837 .

${ }^{36}$ Ibid., at para. 788 .

${ }^{37}$ EEZ Act (n 2), section 61(2).

${ }^{38}$ Trans-Tasman Decision (n 1), at para. 116.

${ }^{39}$ Ibid., at para. 139.
}

${ }^{40}$ This is implied in section 61(3) of the EEZ Act. The precautionary principle is rarely, if ever, absolute. See N. de Sadeleer, Implementing the Precautionary Principle: Approaches from the Nordic Countries, EU and USA (Earthscan, 2012), at p. 363 (discussing the US Occupational Safety and Health Act); C.E. Foster, Science and the Precautionary Principle in International Courts and Tribunals: Expert Evidence, Burden of Proof and Finality (Cambridge University Press, 2011), at p.

233; J. Peel, Science and Risk Regulation in International Law (Cambridge University Press, 2010), at

p. 146 (discussing EC regulatory measures).

${ }^{41}$ EEZ Act (n 2), section 61(3); see also Trans-Tasman Decision (n 1), at para. 140.

${ }^{42}$ Trans-Tasman Decision (n 1), at para. 141. 
The next step in the decision-making process was for the EPA to consider whether taking an adaptive management approach would allow the activity to be undertaken. ${ }^{43}$ The rationale is that an adaptive management approach may sufficiently reduce uncertainty and adequately manage any remaining risk. ${ }^{44}$ An adaptive management approach, as defined in the EEZ Act, includes 'allowing an activity to commence on a small scale or for a short period so that its effects on the environment and existing interests can be monitored'. ${ }^{45}$ The EEZ Act empowers the EPA to 'impose conditions under section 63 that authorize the activity to be undertaken in stages, with a requirement for regular monitoring and reporting before the next stage of the activity may be undertaken or the activity continued for the next period' ${ }^{46}$

Eschewing an adaptive management approach, TTR applied for a full mining consent (that is, the ability to mine the whole area of the application and for the full duration), and rejected the option of a scaled or staged implementation under section 64(3). This was because, for the applicant TTR, 'staging of the activity was not commercially realistic' ${ }^{47}$ The applicant required investment certainty due to the large capital investment required for the proposed mining operations. ${ }^{48}$ Therefore, section 59(2)(j) was not triggered under section 64(3), which would have allowed the EPA to

\footnotetext{
${ }^{43}$ EEZ Act (n 2), section 61(3).

${ }^{44}$ Trans-Tasman Decision (n 1), at para. 850.

${ }^{45}$ EEZ Act (n 2), section 64(2)(a). See also Sustain Our Sounds Incorporated v. The New Zealand King Salmon Company Limited [2014] NZSC 40.

${ }^{46}$ EEZ Act (n 2), section 64(3).

${ }^{47}$ Trans-Tasman Decision (n 1), at para. 144.

${ }^{48}$ Ibid., at para. 795 .
} 
take into account 'the extent to which imposing conditions under section 63 might avoid, remedy, or mitigate the adverse effects of the activity'. ${ }^{49}$

TTR instead proposed a 'risk-based tiered approach', which it argued was in fact an adaptive management approach based on the open-ended definition in section 64(2)(b): 'any other approach that allows an activity to be undertaken so that its effects can be assessed and the activity discontinued, or continued with or without amendment, on the basis of those effects'. Under its 'risk-based tiered approach', TTR 'accept[ed] it may need to alter its operations in order to ensure it complies with whatever quantitative performance standards are eventually established' ${ }^{50}$ The EPA's DMC, however, questioned, first, whether this was akin to adaptive management as defined by the EEZ Act, and second, the extent to which TTR had operational flexibility under the proposed approach to make the necessary changes to, for example, the production rate or depth of mining, in an adaptive manner. ${ }^{51}$ The DMC determined that TTR's proposed package of objectives and conditions 'do not provide sufficient certainty, clarity or robustness on which to form the foundation of an appropriate adaptive management approach, ${ }^{52}$ As a result, it was not clear whether the proposed objectives or conditions could or would achieve the adaptive

\footnotetext{
${ }^{49}$ EEZ Act (n 2), section 59(2)(j). Under section 63(1) of the Act, the EPA has broad powers to impose conditions on marine consents outside of the context of the adaptive management approach under section 64.

${ }^{50}$ Trans-Tasman Decision (n 1), at para. 145.

${ }^{51}$ Ibid., at para. 145.

${ }^{52}$ Ibid., at para. 850 .
} 
management approach goals of 'reducing uncertainty and adequately managing any remaining risk, 53

\section{The Decision}

At the outset, it should be noted that the approach of the EPA's DMC to section 10 of the EEZ Act, which establishes its purpose, marks a turn to strong sustainability in New Zealand decision-making. In the context of section 10, the DMC interpreted key terms and provisions in favour of the 'biophysical bottom line' (strong sustainability) in preference to the more discretionary 'overall broad judgment' (weak sustainability) approach. This presents a progressive development given that the Courts of New Zealand have generally moved towards the 'overall broad judgment' approach to section 5 (Purpose) of the RMA. ${ }^{54}$

The scope of 'economic well-being' in the purpose section was defined very broadly by the DMC. The DMC determined that the EEZ Act is concerned with 'total economic value', which encompasses not just monetary values associated with the activity in question, but also 'the direct and indirect values of [natural] resources as used by others or for their intrinsic and ecosystem services values'. ${ }^{5}$

\footnotetext{
${ }^{53} \mathrm{Ibid}$., at para. 805 (emphasis omitted). The decision in Sustain Our Sounds Incorporated v. The New Zealand King Salmon Company Limited (n 46) made clear that this is a threshold question and must always be considered.

${ }^{54} \mathrm{P}$. Skelton and A. Memon, 'Adopting sustainability as an overarching environmental policy: A review of section 5 of the RMA' (2002) 10 Resource Management Journal; S. Upton, H. Atkins and G. Willis, 'Section 5 re-visited: A critique of Skelton and Memon's analysis' (2002) 10 Resource Management Journal.

${ }^{55}$ Trans-Tasman Decision (n 1), at para. 86.
} 
The ambiguous word 'while' in section 10(2), which also appears in the equivalent section of the RMA, has allowed a wide range of statutory interpretations of the purpose of the RMA. ${ }^{56}$ In the Trans-Tasman Decision it was interpreted by the DMC to mean 'at the same time' ${ }^{57}$ Therefore, it required that 'safeguarding the lifesupporting capacity of the environment' and 'avoiding, remedying, or mitigating any adverse effects of activities on the environment' must be achieved 'at the same time as' economic well-being is enabled. ${ }^{58}$ Such an interpretation, in effect, protects the functional integrity of marine ecosystems as a precondition for people's economic well-being.

The requirement of the EPA to favour caution and environmental protection in light of scientific uncertainty under section 61(2) is, in the DMC's view, 'not to be traded off against the attainment of economic wellbeing, ${ }^{59}$ In a similar vein, the DMC understood that the qualifying words ('the importance of protecting...') that appear in sections $59(2)(d)$ and $59(2)(e)$ were chosen deliberately by law-makers. ${ }^{60}$ Therefore, 'the protection of the intrinsic value of important biological resources' needs to be given more weight than other matters listed under section 59(2), which include 'the economic benefit to New Zealand of allowing the application'. ${ }^{61}$

\footnotetext{
${ }^{56}$ New Zealand Rail Limited v. Marlborough District Council [1994] NZRMA 70; Foxley Engineering Limited v. Wellington City Council, W12/94; LA Campbell and Others v. Southland Regional Council, W114/94; Trio Holdings Limited v. Marlborough District Council [1997] NZRMA 97; North Shore City Council v. Auckland Regional Council [1997] NZRMA 59.

${ }^{57}$ Trans-Tasman Decision (n 1), at para. 87.

${ }^{58}$ Ibid., at para. 87.

${ }^{59}$ Ibid., at para. 139.

${ }^{60}$ Ibid., at para. 106.

${ }^{61}$ EEZ Act (n 2), section 59(f).
} 
The proposed project's potential economic benefit to New Zealand was considered in decision-making. The DMC accepted that the seabed mining operation is likely to have a positive net economic benefit, but concluded that 'these are not "must have" benefits that make it a truly important activity". ${ }^{62}$ Economic benefits other than royalty and tax payments (approximately 50 million New Zealand dollars per annum) were deemed uncertain, and the cost of the potential adverse effects difficult to quantify. ${ }^{63}$

As a result, the DMC concluded that it could not effectively remedy, by the imposition of lawful conditions on the proposed project, the 'uncertainties in the scope and significance of the potential adverse effects, the lack of confidence ... in the extent to which existing interests will be appropriately taken into account and the lack of clarity about the extent of economic benefit to New Zealand outside of royalties and taxes and the economic value of the adverse effects' ${ }^{64}$ The DMC was ultimately "not satisfied that the life-supporting capacity of the environment would be safeguarded or that the adverse effects of the proposal could be avoided, remedied or mitigated', ${ }^{65}$ and decided that the application 'does not meet the sustainable management purpose of the EEZ Act' ${ }^{66}$

\footnotetext{
${ }^{62}$ Trans-Tasman Decision (n 1), at para. 801.

${ }^{63}$ Ibid., at para. 753.

${ }^{64}$ Ibid., at para. 110.

${ }^{65}$ Ibid., at para. 852 .

${ }^{66}$ Ibid., at para. 853 .
} 


\section{Implications for Seabed Mining}

This decision under the EEZ Act teaches a number of lessons for other Pacific Island countries that have growing interests in deep seabed mining as a means of economic development. Papua New Guinea (PNG), for instance, has garnered attention for issuing a commercial deep seabed mining license to a Canadian company Nautilus Minerals. Nautilus is supposed to begin the world's first seabed mining operation on the PNG continental shelf in 2016 and, if successful, will prove the technical and economic viability of seabed mining. ${ }^{67}$ Other Pacific Island developing countries are in the process of designing legal regimes to provide a favourable environment for foreign investment and satisfy those environmentally concerned. ${ }^{68}$ The concern is that these early movers are operating on a set of untested assumptions, namely that seabed mining will raise a significant amount of revenue to stimulate national economic development while preventing serious harm to the marine environment. As illustrated in the Trans-Tasman Decision, however, there may be too many uncertainties at this stage with respect to effects on the environment as well as the economy. In the face of such uncertainties, international law dictates that states apply the precautionary approach in decision-making. ${ }^{69}$ Of course, what the precautionary principle requires

\footnotetext{
${ }^{67}$ See 'Seabed mining - from science fiction to reality', Sydney Morning Herald, 24 August 2014, available at http:/www.smh.com.au/environment/seabed-mining--from-science-fiction-to-reality-20140822106sto.html\#ixzz3D2SbKZEx.

${ }^{68}$ See, e.g., Seabed Minerals Act 2014, No. 10 (2014) (Tonga); Seabed Mining Act 2009 (Cook Islands).

${ }^{69} C f$., Seabed Disputes Chamber of the International Tribunal for the Law of the Sea, Responsibilities and Obligations of States with Respect to Activities in the Area, Advisory Opinion, 1 February 2011,
} 
in specific circumstances has no easy answers and requires careful consideration with as much information as possible.

The EEZ Act provides a model example of how the general international obligation to protect and preserve the marine environment, in relation to precaution, can be translated into national law. As the EEZ Act itself proclaims, it 'continues or enables the implementation of New Zealand's obligations under various international conventions relating to the marine environment, including ... the United Nations Convention on the Law of the Sea 1982 [and] the Convention on Biological Diversity $1992 \cdot{ }^{70}$ It also has important lessons for other countries about how to apply the precautionary principle or the adaptive management approach when making decisions relating to seabed mining activities. This aspect was acknowledged in passing by the EPA's DMC that 'the relevant decision-making criteria and information principles ... reflect the nature of New Zealand's international obligations and embody the appropriate requirements to act with caution and with due regard to uncertainty and the sensitivity of aspects of the marine environment'. ${ }^{71}$ In particular, the requirement to favour caution and environmental protection in light of uncertainty or inadequacy of the information available reflects the precautionary approach as defined by the Seabed Disputes Chamber of the International Tribunal for the Law of the Sea. ${ }^{72}$ The

ITLOS Reports 2011, 10-78, at pp. 45-47; International Court of Justice, Pulp Mills on the River Uruguay (Argentina v. Uruguay), Judgment, ICJ Reports 2010, 14-107, at p. 71.

${ }^{70}$ EEZ Act (n 2), section 11.

${ }^{71}$ Trans-Tasman Decision (n 1), at para. 92; see also para. 93.

${ }^{72}$ Seabed Disputes Chamber of the International Tribunal for the Law of the Sea (n 70), at pp. 45-47. 
DMC was reluctant to call it a precautionary approach, and rather labels it a 'cautious approach' whereby the 'taking of risks in this environment is not encouraged'. ${ }^{73}$

From an international perspective, however, there is a noteworthy limitation in terms of the geographical scope of concern. The environment, under the EEZ Act, is restricted to 'the natural environment, including ecosystems and their constituent parts and all natural resources, of (a) New Zealand[,] (b) the exclusive economic zone[,] (c) the continental shelf[,] (d) the waters beyond the exclusive economic zone and above and beyond the continental shelf ${ }^{74}$ Therefore, potential transboundary impact on the Area - the common heritage of mankind - is not required to be taken into account by the EPA when considering an application for a marine consent. This appears inconsistent with New Zealand's obligations under the United Nations Convention on the Law of the Sea, such as the duty not to transfer damage or hazards from one area to another. ${ }^{75}$

The Trans-Tasman Decision has a few important implications for future seabed mining projects in New Zealand and beyond. First, adequate information on effects on the environment and other existing interests is prerequisite for any seabed

\footnotetext{
${ }^{73}$ Trans-Tasman Decision (n 1), at para. 139; Seabed Disputes Chamber of the International Tribunal for the Law of the Sea, Responsibilities and Obligations of States with Respect to Activities in the Area, Advisory Opinion, 1 February 2011, ITLOS Reports 2011, 10-78, at pp. 45-47. See Donald K. Anton, Robert A. Makgill \& Cymie R. Payne, Seabed Mining: Advisory Opinion on Responsibility and Liability (2011) 41 Environmental Policy and Law 60; M. van Kampen, 'The adequacy of legislation regulating the environmental effects of mining' (2012) 16 New Zealand Journal of Environmental Law 203-242, at p. 239.

${ }^{74}$ EEZ Act (n 2), section 4 (emphasis added); see also sections 59(2)(a)(ii) and 59(2)(b)(ii).

${ }^{75}$ United Nations Convention on the Law of the Sea (Montego Bay, 10 December 1982, in force 16 November 1994) 1833 UNTS 396, Article 195.
} 
mining activities. In particular, longitudinal baseline monitoring data extending over at least a few years (as opposed to modelled information) is essential. Second, tradeoffs between investment certainty and the adaptive management approach will need to be taken into consideration by seabed miners. Seabed miners may need to take greater risk by accepting a scaled or staged implementation, but this may render seabed mining commercially unviable. Third, seabed miners will need to offer a fair share of economic benefits to the people and the country. Economic benefits through taxes and royalties alone were deemed insignificant in this case, especially in the face of large uncertainties in terms of adverse economic effects on existing interests such as fisheries.

It is conceivable that future seabed mining consent applications will pass the information adequacy test. The EPA's DMC repeatedly assured in its decision that the applicant could have done differently for a higher chance of getting the consent. ${ }^{76}$ Perhaps the greater challenge from a governance perspective is the inherent tension between providing a stable environment for investment and applying an adaptive management approach. What this DMC's decision highlights is that, under the EEZ Act, miners will need to accept some degree of risk from undertaking adaptive and flexible seabed mining, and give the EPA the required confidence that adverse effects of seabed mining will be effectively avoided, remedied, or mitigated, and not significantly undermine the life-supporting capacity of the environment.

\footnotetext{
${ }^{76}$ For example, the DMC stated that 'at least some of these matters could have been addressed contemporaneously with the other investigative work the applicant undertook prior to lodging the application for consents'. Trans-Tasman Decision (n 1), at para. 853.
} 


\section{Conclusion}

Building on the nation's 20-year experience with the RMA, the EEZ Act has advanced the frontiers of natural resource management. The precautionary and adaptive management approaches in the Act have proven effective in decision-making in the seabed mining context. It seems clear that the EPA applied the law appropriately in favouring environmental protection over other interests. However, the decision was appealed on a question of law by the applicant in July 2014. The interpretation of the provisions of the EEZ Act by the EPA's DMC will be subject to scrutiny in the High Court of New Zealand. The EEZ Act's real potential is, therefore, yet to be determined. 